\title{
Penyembuhan Ulkus Diabetik dengan Aplikasi Antimikrobial Wound Dressing Silver (Acticoat ${ }^{\mathrm{TM}}$ )
}

\author{
Nila Indrayati ${ }^{1}$,Yeni Koto $^{2}$, Budhi Mulyadi ${ }^{3}$ \\ ${ }^{1,2,3}$ Program Sarjana Ilmu Keperawatan \\ Sekolah Tinggi Ilmu Kesehatan Indonesia Maju \\ Jln. Harapan Nomor 50, Lenteng Agung - Jakarta Selatan 12610 \\ Telp: (021) 78894045, Email : indrayati_nila@yahoo.com, Kyoto.yeni16@gmail.com, \\ bemulyadi74@gmail.com
}

\begin{abstract}
Abstrak
Penanganan ulkus diabetic membutuhkan advanced wound management berupa antimikrobial dressing, karena luka yang tidak kunjung sembuh, salah satu penyebabnya karena kumpulan berbagai jenis bakteri dan disertai biofilm. Balutan Silver (Acticoat ${ }^{\mathrm{TM}}$ ) merupakan salah satu produk antimikrobial.Tujuan dari penelitian ini adalah untuk mengetahui efektivitas balutan silver terhadap penyembuhan ulkus diabetik. Metode penelitian menggunakan desain quasi-eksperiment, pre-test-post-test. Menggunakan instrumen luka yang sudah baku, yaitu Status Kontinum Bates Jensen Wound Assessment Tools (BWAT). Hasil univariat didapatkan bahwa pada kelompok kontrol yang menggunakan Cutimed Sorbact ${ }^{\circledR}$, jenis kelamin dan usia responden terbanyak adalah wanita sebanyak $71,43 \%$ dan usia $61-70$ tahun sebanyak 50,00\%.Pada kelompok eksperimen yang menggunakan Acticoat ${ }^{\mathrm{TM}}$, jenis kelamin terbanyak adalah wanita sebanyak $62,50 \%$ dan usia $61-70$ tahun sebanyak 57,14\%. Hasil uji independent T-test yang membandingkan pre dan post didapatkan nilai $p$-value 0,011 dengan tingkat signifikansi $<0,05$ sehingga dapat disimpulkan bahwa ada perbedaan yang signifikan antara hidrophobic (Cutimed Sorbact ${ }^{\circledR}$ ) dan silver (Acticoat TM) . Penggunakan Silver (Acticoat TM) memiliki respon yang lebih baik, dibuktikan oleh tingkat kesembuhan yang tinggi dan waktu yang dibutuhkan untuk penyembuhan lebih cepat dari yang diharapkan. Saran yang diharapakan semoga penelitian ini dapat menjadi sumber referensi dalam mengembangkan ilmu keperawatan sebagai prosedur baru dalam penanganan ulkus diabetik dengan menggunakan antimirobial
\end{abstract}

Kata kunci $\quad$ : ulkus diabetik, hydrophobic, perak

\begin{abstract}
Treatment of diabetic ulcer, requires advanced wound management in the form of antimicrobial dressings, wounds that do not heal, met by a collection of various types of bacteria and biofilm accompanied. Silver dressings (Acticoat TM) is one of the antimicrobial product. The purpose of this study was to determine the effectiveness of silver dressings on healing diabetic ulcers. The research method using a quasi-experimental design, methods of control group pre-test-post-test. Using instruments that already raw wound, the Continuum Status Bates Jensen Wound Assessment Tools (bwat).. Results of univariate found that in a control group using the application Cutimed Sorbact $\AA^{\circledR}$, sex and age of the most respondents as much as $71.43 \%$ are female and aged $61-70$ years as much as $50.00 \%$. In the experimental group using Acticoat $\mathrm{TM}$, most are women as much as $62.50 \%$ and $61-70$ years of age as much as $57.14 \%$. The test results independent T-test comparing pre and post values obtained p-value 0.011 with a significance level of $<0.05$ so that it can be concluded that there is a significant difference between hidrophobic (Cutimed Sorbact $₫$ ) and silver (Acticoat $\mathrm{TM})$. The use of Silver (Acticoat $\mathrm{TM})$ have a better response, evidenced by the high cure rate and the time required for healing faster than expected. It is expected that this research can be a reference source in developing nursing science as a new procedure for treating diabetic ulcers using antimirobial
\end{abstract}

Keywords $\quad$ : diabetic ulcer, hydrophobic, silver 


\section{Pendahuluan}

Diabetes melitus merupakan suatu penyakit menahun yang ditandai dengan kadar glukosa darah (gula darah) melebihi nilai normal yang dapat menyebabkan komplikasi pada berbagai sistem tubuh salah satunya yaitu ulkus diabetik yang merupakan komplikasi kronik. ${ }^{1}$

Ulkus diabetik merupakan luka terbuka pada permukaan kulit karena adanya komplikasi makroangiopati. Gejala yang sering dikeluhkan yaitu sering kesemutan, nyeri pada kaki seperti rasa terbakar, tidak berasa, kerusakan jaringan (nekrosis), penurunan denyut nadi, kaki menjadi atrofi, dingin, dan menebal, serta kulit menjadi kering. ${ }^{2}$ Penderita sering tidak merasakan adaanya luka dan mudah berkembang menjadi infeksi, karena kontaminasi bakteri aerob maupun anaerob. Jenis patogen yang biasa terdapat pada luka kronik antara lain Staphilococcus aureus, Pseudomonas aeroginosa, E. coli, Entercocci, dan Candida albinicans. Jika tidak tertangani, maka akan terjadi ganggren dan harus diamputasi. Diperkirakan bahwa setiap 20 detik terdapat amputasi ekstremitas bawah karena ulkus diabetik. ${ }^{3}$

Penanganan ulkus diabetik, membutuhkan Advanced Wound Management berupa antimikrobial dressing. ${ }^{4}$ Terdapat beberapa jenis produk antimikrobial yang telah digunakan dalam perawatan luka antara lain silver, iodine, madu, hydrophobic dan $P H M B$. Sayangnya belum ada rujukan yang jelas mana antimikrobial yang paling baik.Hal inilah yang membuat peneliti tertarik untuk melakukan riset membandingkan produk antimikrobial yang paling efektif terhadap penyembuhan ulkus diabetik. Produk yang akan diteliti adalah dressing Silver (Acticoat ${ }^{\mathrm{TM}}$ ) dan Hydrophobic (Cutimed Sorbact $\left.{ }^{\circledR}\right)$.

Cutimed Sorbact ${ }^{\circledR}$ adalah dressing berbahan katun yang dilapisi DACC (dialkycarbamoylchloride), derivate dari asam lemak. Kandungan tersebut merupakan suatu zat yang memiliki sifat hydrophobic yang kuat pada dressing. Bakteri pada luka, secara irreversibel akan terikat pada dressing saat bersentuhan dengan serat hidrofobiknya.
Setelah bakteri luka terikat pada dressing, bakteri tidak akan terlepas dari dressing. Saat terikat pada Cutimed Sorbact ${ }^{\circledR}$, bakteri menjadi inaktif dan metabolismenya diperlambat. Akibatnya, replikasi bakteri menjadi minimal, demikian pula pembentukan toksin bakteri yang menghambat penyembuhan luka. Manfaat lebih dibandingkan zat kimiawi aktif lainnya seperti perak adalah bahwa dengan Cutimed Sorbact $^{\circledR}$, patogen secara efektif terikat tetapi tidak dihancurkan, sehingga tidak terjadi pelepasan endotoksin bakteri. Keadaan seperti ini membantu terbentuknya kondisi luka yang optimal untuk penyembuhan secara alami.

Komposisi Acticoat ${ }^{\mathrm{TM}}$ terdiri dari Polyester core yang secara farmakologi berfungsi untuk menjaga kelembaban, polyethylene mesh untuk memudahkan bagian silver melalui dressing dan nanocrystalline silver coating untuk menghantarkan antimikroba bekerja, selain itu konsentrasi silver pada Acticoat ${ }^{\mathrm{TM}}$ sebesar 70-100 ppm sehingga memiliki efek antimikrobial spektrum luas.

Mekanisme kerja dari Acticoat ${ }^{\mathrm{TM}}$ adalah dengan cara Oligodynamic ag + yaitu, silver akan melakukan penetrasi ke dalam membrane sel bakteri dan dikarenakan ukurannya yang sangat kecil (nano partikel) penetrasi dari olygodinamic ag+ dapat mengubah integritas membran sel, ikatan esensial protein dan DNA pada mikroorganisme sehingga menjadi tidak stabil dan metabolisme sel mulai mengalami proses kehancuran dimana reaksi enzim esensial yang mengatur kehidupan sel mikroorganisme menjadi lumpuh dan menyebabkan mikroorganisme tidak bisa membelah diri dan sel-sel imun tubuh menjalankan fungsi fagositasnya dengan menelan dan menghancurkan mikroorganisme. Pelepasan Ion $\mathrm{Ag}+$ ini baru dapat terjadi apabila silver dalam kondisi basah sehingga $\mathrm{Ag0}+\mathrm{H} 2 \mathrm{O}$ akan menjadi $\mathrm{Ag}+$. Ion $\mathrm{Ag}+$ Acticoat $^{\mathrm{TM}}$ akan bekerja lepas lambat hingga 72 jam dimana akan mulai bekerja dalam waktu 30 menit sudah terjadi penetrasi ke luka dan bakteri karena bentuk kristal dan ukuran nanonya. Ion $\mathrm{Ag}+$ akan langsung berikatan dengan protein dari bakteri seperti protein pada reseptor 
membran sel, protein DNA \& RNA sehingga akan membunuh bakteri.

Dokumen Konsensus Internasional menyatakan bahwa antimikrobial topikal harus memiliki efek positif dalam waktu 2 minggu. Dalam sebuah studi klinis komparatif luka kronis, $60 \%$ dari pasien yang diobati dengan Acticoat ${ }^{\mathrm{TM}}$ menunjukan hasil positif pada infeksinya dalam waktu 2 minggu. Kecepatan dalam membunuh bakteri sangat penting karena bakteri berkembang biak sangat pesat.

\section{Metode}

Jenis penelitian ini menggunakan desain Quasy-Eksperiment, kontrol group pretest-post-test. Alat pengumpul data pada penelitian ini menggunakan instrumen yang sudah baku, yaitu Wound Status Continuum Bates Jensen Wound Assessment Tools.Unsur yang dikaji adalah : ukuran, kedalaman, tepi luka, undermining, tipe jaringan nekrotik, jumlah jaringan nekrotik, tipe eksudat, jumlah eksudat, warna kulit sekitar luka, jaringan edema perifer, indurasi jaringan perifer, jaringan granulasi, dan jaringan epitelisasi.

Jumlah populasi ulkus diabetik adalah 54. Pemilihan responden menggunakan teknik purposive sampling. Kriteria inklusi dalam penelitian ini adalah semua pasien yang menderita ulkus diabetik yang berobat jalan ke klinik RMC Depok mulai tanggal 16 Agustus 2016 hingga 16 Januari 2017; memiliki kesadaran compos mentis dan mampu berkomunikasi dengan baik; serta yang telah menandatangani lembar persetujuan. Kriteria eksklusi dalam penelitian ini adalah: pasien yang tidak bersedia menjadi sampel penelitian, pasien yang mempunyai kondisi penurunan kesadaran dan pasien mempunyai komplikasi penyakit jantung dan gagal ginjal.

Sampel yang diteliti sebanyak 15 responden, dibagi menjadi 2 kelompok yang dibandingkan, yaitu 8 responden kelompok kontrol yang dirawat dengan menggunakan Cutimed Sorbact ${ }^{\circledR}$ dan 7 responden kelompok eksperimen yang dirawat dengan Acticoat ${ }^{\mathrm{TM}}$. Pada perawatan dengan hydrophobic (Cutimed Sorbact $\left.{ }^{\circledR}\right)$ dan silver (Acticoat ${ }^{\mathrm{TM}}$ ) pengamatan dilakukan sesuai jadwal penggantian balutan tiap 3 hari sekali.

\section{Hasil}

Hasil penelitian ini dikelompokkan menjadi dua yaitu data umum mengenai karakteristik klinik, umur dan jenis kelamin pasien ulkus diabetik. Data khusus terdiri dari kondisi ulkus diabetik sebelum dan setelah dilakukan terapi antimikrobial hydrophobic (Cutimed Sorbact ${ }^{\circledR}$ ) dan silver (Acticoat ${ }^{\mathrm{TM}}$ ) dan perbandingan antara terapi antimikrobial hydrophobic (Cutimed Sorbact ${ }^{\circledR}$ ) dan silver (Acticoat ${ }^{\mathrm{TM}}$ ) terhadap penyembuhan ulkus diabetik

Tabel 1. Distribusi Pasien Ulkus Diabetik Berdasarkan Jenis Kelamin di Klinik Raditya Medical Center Depok, Bulan Agustus 2016 Januari 2017. N=15

\begin{tabular}{llcr}
\hline Kelompok & $\begin{array}{l}\text { Jenis } \\
\text { kelamin }\end{array}$ & Frekuensi & \multicolumn{1}{c}{$\%$} \\
\hline Eksperimen & Laki-laki & 2 & 28,58 \\
& wanita & 5 & 1,43 \\
\multirow{2}{*}{ Kontrol } & Laki-laki & 3 & 37,51 \\
& wanita & 5 & 2,50 \\
\hline
\end{tabular}

Berdasarkan tabel 1, karakteristik pasien ulkus diabetik menurut jenis kelamin, pada kelompok eksperimen lebih banyak pada wanita yaitu 5 orang $(71,3 \%)$ Pada kelompok kontrol, lebih banyak berjenis kelamin wanita yaitu 5 orang $(62,5 \%)$.

Tabel 2. Distribusi Pasien Ulkus Diabetik Berdasarkan Usia di Klinik Raditya Medical Center Depok, Bulan Agustus 2016-Januari 2017

\begin{tabular}{lccc}
\hline Kelompok & Usia & Frekuensi & $\%$ \\
\hline Eksperimen & $71-80$ & 0 & 0,00 \\
& $61-70$ & 3 & 42,86 \\
& $51-60$ & 4 & 57,14 \\
Kontrol & $71-80$ & 1 & 12,50 \\
& $61-70$ & 4 & 50,00 \\
& $51-60$ & 3 & 37,50 \\
\hline
\end{tabular}

Berdasarkan tabel 2, menunjukkan bahwa karakteristik responden berdasarkan usia pada kelompok eksperimen lebih banyak menyerang pada usia 51 - 60 tahun yaitu sejumlah 4 pasien $(57,14 \%)$ dan terendah adalah pada kelompok usia 71 - 80 tahun yaitu 
0 pasien $(0,00 \%)$ sedangkan pada kelompok kontrol usia yang terbanyak diserang adalah golongan usia 61 - 70 tahun yaitu sejumlah 4 pasien $(50,00 \%)$ dan usia terendahnya adalah $71-80$ tahun yaitu 1 pasien $(12,50 \%)$.

Tabel 3. Distribusi Rata-Rata Skor Ulkus Diabetik pada Kelompok Kontrol Sebelum dan Setelah Aplikasi Antimikrobial Hydrophobic (Cutimed Sorbact ${ }^{\circledR}$ ) di Klinik Raditya Medical Center Depok, Bulan Agustus 2016Januari 2017

\begin{tabular}{cccc}
\hline Responden & $\begin{array}{c}\text { Skor } \\
\text { Pretest }\end{array}$ & $\begin{array}{c}\text { Skor } \\
\text { Postest }\end{array}$ & Selisih \\
\hline R1 & 46 & 10 & 36 \\
R2 & 54 & 21 & 33 \\
R3 & 34 & 7 & 27 \\
R4 & 41 & 23 & 18 \\
R5 & 52 & 28 & 24 \\
R6 & 41 & 10 & 31 \\
R7 & 35 & 8 & 27 \\
R8 & 38 & 8 & 30 \\
& & & \\
Mean & 42,62 & 14,38 & 28,25 \\
\hline
\end{tabular}

Berdasarkan tabel 3, menunjukkan bahwa rata-rata skor luka sebelum aplikasi balutan antimikrobial hydrophobic (Cutimed Sorbact $($ ) adalah 42,62 .Skor luka paling tinggi adalah 54 dan paling rendah adalah 34 . Pada tabel ini juga menunjukkan rata-rata skor luka setelah dilakukan aplikasi balutan antimikrobial hydrophobic (Cutimed Sorbact ${ }^{\circledR)}$ adalah 14,38 . Skor luka paling tinggi adalah 28 dan yang paling rendah adalah 7.

Tabel ini menunjukkan penurunan skor luka setelah diberikan aplikasi Hydrophobic (Cutimed Sorbact $\left.{ }^{\circledR}\right)$ yaitu ratarata penyembuhan luka sebanyak 28,25.

Tabel 4. Distribusi Proses Penyembuhan Ulkus Diabetik pada Kelompok Kontrol dengan Terapi Antimikrobial Hydrophobic (Cutimed Sorbact ${ }^{\circledR}$ ) di Klinik Raditya Medical Center Depok, Bulan Agustus 2016Januari 2017 ( $\mathrm{n}=8)$

\begin{tabular}{ccc}
\hline Responden & Stage & Stage \\
& Pretest & Post test \\
\hline
\end{tabular}

\begin{tabular}{lll} 
R1 & Regenerasi & Sembuh \\
R2 & Regenerasi & Regenerasi \\
R3 & Regenerasi & Sembuh \\
R4 & Regenerasi & Regenerasi \\
R5 & Regenerasi & Regenerasi \\
R6 & Regenerasi & Sembuh \\
R7 & Regenerasi & Sembuh \\
R8 & Regenerasi & Sembuh \\
\hline
\end{tabular}

Berdasarkan tabel 4 dapat disimpulkan bahwa penyembuhan ulkus pada kelompok kontrol adalah dari 8 responden terdapat $5(62 \%)$ responden yang mengalami penyembuhan dan $3(38 \%)$ responden masih dalam kondisi regenerasi luka.

Tabel 5. Distribusi Rata-Rata Skor Ulkus Diabetik pada Kelompok Eksperimen Sebelum dan Setelah Aplikasi Antimikrobial Silver (Acticoat ${ }^{\mathrm{TM}}$ ) di Klinik Raditya Medical Center Depok, Bulan Agustus 2016-Januari

\begin{tabular}{cccc}
\hline Responden & $\begin{array}{c}\text { Skor } \\
\text { Pretest }\end{array}$ & $\begin{array}{c}\text { Skor } \\
\text { Postest }\end{array}$ & Selisih \\
\hline R9 & 41 & 7 & 34 \\
R10 & 57 & 26 & 31 \\
R11 & 54 & 10 & 44 \\
R12 & 57 & 8 & 49 \\
R13 & 50 & 7 & 43 \\
R14 & 52 & 12 & 40 \\
R15 & 46 & 8 & 38 \\
& & & \\
Mean & 51,00 & 11,14 & 38,43 \\
\hline
\end{tabular}

Berdasarkan tabel 5, menunjukkan bahwa rata-rata skor luka sebelum aplikasi antimikrobial silver (Acticoat ${ }^{\mathrm{TM}}$ ) adalah 51.00. Skor luka paling tinggi berada di angka skor 57 dan paling rendah di angka skor 41 . Pada tabel ini juga menunjukkan bahwa ratarata skor luka setelah aplikasi antimikrobial silver (Acticoat ${ }^{\mathrm{TM}}$ ) adalah 11,14. Skor luka paling tinggi berada di angka skor 26 dan paling rendah di angka skor 7. Tabel ini menunjukkan penurunan rata-rata penyembuhan luka sebanyak 38,43 . 
Tabel 6. Distribusi Proses Penyembuhan Ulkus Diabetik pada Kelompok Eksperimen dengan Aplikasi Antimikrobial Silver (Acticoat $^{\mathrm{TM}}$ ) di Klinik Raditya Medical Center Depok, Bulan Agustus 2016-Januari $2017(\mathrm{n}=7)$

\begin{tabular}{llc}
\hline Responden & $\begin{array}{c}\text { Stage } \\
\text { Pre test }\end{array}$ & $\begin{array}{c}\text { Stage } \\
\text { Post test }\end{array}$ \\
\hline R9 & Regenerasi & Sembuh \\
R10 & Degenerasi & Regenerasi \\
R11 & Regenerasi & Sembuh \\
R12 & Degenerasi & Sembuh \\
R13 & Regenerasi & Sembuh \\
R14 & Regenerasi & Sembuh \\
R15 & Regenerasi & Sembuh
\end{tabular}

Berdasarkan tabel 6, dapat disimpulkan bahwa penyembuhan ulkus diabetik pada kelompok eksperimen adalah dari 7 responden terdapat 6 $(86 \%)$ responden yang mengalami penyembuhan dan $1(14 \%)$ responden dalam kondisi regenerasi luka.

Berdasarkan hasil uji normalitas Shapiro-Wilk diperoleh hasil nilai signifikasi kelompok kontrol sebesar 0.914 dan kelompok eksperimen 0,793. Karena nilai signifikasi > 0,05 sehingga data dikatakan berdistribusi normal.

Langkah selanjutnya adalah melakukan uji beda Independent sample t test, karena di samping jumlah sampelnya kecil yaitu 15 ( $<=30$ kasus), juga untuk mengetahui apakah terdapat perbedaan rata-rata kedua populasi dengan melihat rata-rata kedua sampelnya.

Hasil uji independent sample t-test didapatkan nilai $p$-value sebesar 0,011 dengan taraf signifikansi $<0,05$ sehingga dapat disimpulkan bahwa ada perbedaan pengaruh yang bermakna antara hydrophobic (Cutimed Sorbact ${ }^{\circledR}$ ) dan silver (Acticoat ${ }^{\mathrm{TM}}$ ) terhadap proses penyembuhan ulkus diabetik.

\section{Pembahasan}

\section{Pengaruh Jenis Kelamin Terhadap Penyembuhan Ulkus Diabetik}

Berdasarkan hasil penelitian, pada kelompok kontrol dengan aplikasi antimikrobial hydrophobic (Cutimed Sorbact $\left.{ }^{\circledR}\right)$, sebanyak $71,43 \%$ berjenis kelamin wanita. Demikian juga pada kelompok eksperimen dengan aplikasi antimikrobial silver (Acticoat ${ }^{\mathrm{TM}}$ ), sebanyak $62,50 \%$ berjenis kelamin wanita.

Hal ini sesuai dengan penelitian Ferawati (2014), yang menunjukkan bahwa wanita berisiko terhadap terjadinya ulkus diabetik. Hal ini disebabkan karena adanya perubahan hormonal pada perempuan yang memasuki masa menopause. Hasil penelitian serupa juga pernah dilakukan oleh Purwanti (2013) yang menyatakan bahwa terdapat $64,7 \%$ responden berjenis kelamin perempuan yang menderita diabetes mellitus dibandingkan jenis kelamin laki-laki.

Nurlaily (2014) meneliti tentang faktor penyebab penyakit diabetes mellitus lebih banyak dialami oleh wanita daripada laki-laki. Hal tersebut dikarenakan tiga faktor. Faktor pertama yaitu kadar kolesterol HDL, LDL, dan trigliserida lebih tinggi pada perempuan daripada laki-laki, ${ }^{5,6}$. Penelitian pada tahun 2012 oleh Waspadji menghasilkan bahwa kadar trigliserida merupakan faktor risiko terjadi penyakit pembuluh darah perifer yang dapat mengakibatkan terjadinya ulkus diabetika. ${ }^{7}$ Faktor kedua adalah penurunan sensitivitas insulin.

Menurut peneliti, jenis kelamin merupakan salah satu faktor resiko terjadinya ulkus kaki diabetik khususnya pada wanita. Usia merupakan faktor resiko kedua yang menjadi penyebab terjadinya ulkus kaki diabetik.

\section{Pengaruh Usia Terhadap Penyembuhan Ulkus Diabetik}

Berdasarkan penelitian ini, didapatkan hasil bahwa kelompok eksperimen lebih banyak pada usia 51 - 60 tahun yaitu sejumlah 4 pasien $(57,14 \%)$,kelompok kontrol lebih banyak pada usia 61 - 70 tahun yaitu sejumlah 4 pasien $(50,00 \%)$.Usia lanjut berisiko terhadap terjadinya ulkus diabetikum, karena fungsi tubuh secara fisiologis menurun, hal ini disebabkan karena penurunan sekresi atau resistensi insulin, sehingga kemampuan fungsi 
tubuh terhadap pengendalian glukosa darah yang tinggi kurang optimal ${ }^{8}$.

\section{Pengaruh Antimikrobial Hydrophobic (Cutimed Sorbact ${ }^{\circledR}$ ) silver (Acticoat ${ }^{\mathrm{TM}}$ ) Terhadap Penyembuhan Ulkus Diabetik}

Berdasarkan tabel 3, menunjukkan bahwa rata-rata skor luka setelah dilakukan tindakan rawat luka modern dengan terapi antimikrobial hydrophobic (Cutimed Sorbact $\left.{ }^{\circledR}\right)$ adalah 14,38 .Skor luka paling tinggi berada di angka skor 28 dan paling rendah di angka skor 7. Berdasarkan tabel 4 dapat disimpulkan bahwa seluruh responden ulkus diabetik kelompok kontrol mengalami penurunan rata-rata penyembuhan ulkus diabetik terbukti dari 8 responden terdapat 5 responden yang mengalami penyembuhan dan 3 responden lainnya masih dalam kondisi regenerasi luka.Penurunan rata-rata penyembuhan luka sebanyak 28,24 dari nilai rata-rata pretest 42,62 dan nilai rata-rata posttest 14,38. Berdasarkan tabel 5, menunjukkan bahwa rata-rata skor luka pada kelompok eksperimen setelah dilakukan tindakan rawat luka modern dengan terapi antimikrobial silver (Acticoat ${ }^{\mathrm{TM}}$ ) adalah 11,14. Skor luka paling tinggi berada di angka 27 dan paling rendah di angka 7.Berdasarkan tabel 6 dapat disimpulkan bahwa seluruh responden ulkus diabetik kelompok eksperimen mengalami penurunan rata-rata penyembuhan ulkus diabetik terbukti dari 7 responden terdapat 6 responden yang mengalami penyembuhan dan 1 responden lainnya masih dalam kondisi regenerasi luka. Tabel menunjukkan penurunan rata-rata penyembuhan luka sebanyak 39,86 dari nilai rerata pretest 51,00 dan nilai rata-rata posttest 11,14 .

\section{Perbedaan Pengaruh Terapi Antimikrobial Hydrophobic pada Kelompok kontrol Dibandingkan Terapi Antimikrobial Silver pada Kelompok Eksperimen.}

Berdasarkan tabel di atas, hasil uji independent sample T-test yang membandingkan selisih pre dan post antara kelompok eksperimen dan kelompok kontrol didapatkan nilai Sig.(2-tailed) sebesar 0,011 dengan taraf signifikansi $<0,05$ sehingga dapat disimpulkan bahwa ada perbedaan pengaruh yang bermakna antara hydrophobic (Cutimed Sorbact $\left.{ }^{\circledR}\right)$ dan silver (Acticoat). Hasil penelitian ini menunjukkan, adanya penurunan skor luka yang lebih signifikan pada kelompok eksperimen dibandingkan kelompok kontrol yaitu 38,43 berbanding 28,25 . Di samping itu tingkat kesembuhan responden lebih banyak pada kelompok ekperimen dibandingkan dengan kelompok kontrol, yaitu dari 7 responden terdapat 6 responden dinyatakan sembuh tetapi hanya ada 1 orang yang belum sembuh.Sedangkan pada kelompok kontrol dari 8 responden hanya 5 responden yang lukanya dinyatakan sembuh sedangkan 3 responden lainnya belum sembuh. Hal ini disebabkan karena karakteristik silver perak, menurut Cahyaningsih (2015), dengan efek oligodynamic yang terdapat di nanosilver akan membantu sel $\mathrm{T}$ untuk melawan mikroorganisme asing yang ada di dalam darah,membentuk sistim imun sekunder dengan cara turut campur dalam membunuh bakteri yang merugikan bagi sel . Efek oligodynamic ag + akan melakukan penetrasi ke dalam membrane sel bakteri dan dikarenakan ukurannya yang sangat kecil (nano partikel) penetrasi dari oligodinamik ag+ dapat mengubah integritas membran sel, ikatan esensial protein dan DNA pada mikroorganisme sehingga menjadi tidak stabil dan metabolisme sel mulai mengalami proses kehancuran dimana reaksi enzim esensial yang mengatur kehidupan sel mikroorganisme menjadi lumpuh dan menyebabkan mikroorganisme tidak bisa membelah diri dan sel-sel imun tubuh menjalankan fungsi fagositasnya dengan menelan dan menghancurkan mikroorganisme yang menghantarkan antimikroba bekerja dalam waktu 30 menit lebih cepat dibandingkan dengan antimikrobial lainnya, selain itu konsentrasi silver pada Acticoat ${ }^{\mathrm{TM}}$ sebesar 70 sampai $100 \mathrm{ppm}$ memiliki efek antimikrobial spektrum luas. ${ }^{9}$ Dalam sebuah studi klinis komparatif luka kronis, $60 \%$ dari pasien yang diobati dengan Acticoat ${ }^{\mathrm{TM}}$ menunjukan hasil positif pada infeksinya dalam waktu 2 minggu.Acticoat ${ }^{\mathrm{TM}}$ bekerja efektif terhadap \pm 150 bakteri patogen, candida, MRSA (Methicillin Resistant Staphylococcus Aureus), VRSA (Vancomycin Resistant Staphylococcus 
Aureus) dan VRE (Vancomycin Resistant Enterccocus). ${ }^{10.11}$

\section{Kesimpulan}

Berdasarkan penelitian yang dilakukan pada kelompok kontrol, yaitu pasien ulkus diabetik yang diberikan aplikasi balutan antimikrobial hydrophobic (Cutimed Sorbact $\left.{ }^{\circledR}\right)$ dan kelompok eksperimen yang diberikan aplikasi balutan silver (Acticoat ${ }^{\mathrm{TM}}$ ), dapat disimpulkan bahwa, keunggulan antimikroba jenis hydrophobic adalah selain harganya murah, dapat digunakan dalam jangka waktu yang lama dan aman untuk digunakan pada wanita hamil dan anak kecil karena tidak mengandung bahan toksik sehingga penyembuhan lebih alami walaupun waktu kesembuhannya lebih lama.

Keunggulan antimikrobial jenis silver (Acticoat ${ }^{\mathrm{TM}}$ ) terhadap proses penyembuhan ulkus diabetik adalah waktu yang dibutuhkan oleh Acticoat ${ }^{\mathrm{TM}}$ untuk mulai bekerja membunuh bakteri telah terbukti secara invitro dalam waktu 30 menit, karena kandungan nanosilvernya sebesar 70-100 ppm sehingga memiliki efek olygodinamik dan antimikrobial spektrum luas, sehingga waktu penyembuhannya lebih cepat walapun biaya yang dibutuhkan lebih mahal.

Selama pengamatan diperoleh data responden ulkus diabetik lebih banyak menyerang pada wanita dan lansia.Tingkat kesembuhan pada kelompok ekperimen lebih banyak dan lebih cepat waktunya dibandingkan kelompok kontrol. Sehingga Pengaruh produk antimikrobial dressing yang paling efektif terhadap penyembuhan ulkus diabetik adalah silver ( Acticoat ${ }^{\mathrm{TM}}$ ).

\section{Saran}

Hasil penelitian ini dapat memberikan manfaat bagi Klinik Raditya Medical Center Depok dalam menangani ulkus diabetik agar lebih baik lagi. Bagi institusi pendidikan, dapat menjadi sumber referensi dalam mengembangkan ilmu keperawatan sebagai prosedur baru dalam penanganan ulkus diabetik dengan menggunakan antimirobial. Bagi profesi keperawatan, hasil penelitian ini dapat menjadi sumber informasi, rujukan, dan bahan acuan tambahan dalam mengaplikasikan
SOP (Standart Operational Procedure) rawat luka dalam memberikan asuhan keperawatan kepada pasien dengan ulkus diabetik serta dapat mengembangkan ilmu keperawatan khususnya di bidang rawat luka bagi rekan sejawat yang membuka lahan praktek perawatan luka, bagi masyarakat dan responden.Hasil penelitian ini dapat memberikan manfaat bagi masyarakat khususnya responden yaitu menjadi masukan bahwa terapi antimikrobial dapat dijadikan alternatif pengobatan terbaru dalam menangani masalah ukus diabetik dengan rawat luka modern sehingga meyakinkan pada masyarakat bahwa luka ulkus diabetik dapat disembuhkan. Bagi Peneliti Penelitian ini dapat menjadi awal dari penelitian selanjutnya yang terkait dengan penanganan ulkus diabetik sehingga harapannya dengan adanya penelitian ini, peneliti dapat menemukan berbagai solusi untuk mengatasi permasalahan ulkus diabetik. Penelitian lanjutan perlu dilakukan untuk menyempurnakan hasil dari penelitian ini bahwa metode rawat luka modern.

\section{Daftar Pustaka}

1. Sudoyo, A.W., Setiyohadi, B., Alwi, I., Simadibrata, M., \& Setiati, S. Buku ajar ilmu penyakit dalam jilid III edisi 5 Jakarta; Interna Publishing; 2009.

2. Prince and Wilson. Patofisiologi Konsep Klinis Proses-Proses Penyakit, edisi ke 6; Jakarta; 2012.

3. Triyanisya. Jumlah Penyandang Diabetes di Indonesia Terbanyak ketujuh di Dunia. Metrotvnews. Diperoleh tanggal 3 Juli 2016 darihttp://www.metrotvnews.com

4. David Parsons, PhD; Philip G. Bowler, MPhil; Viv Myles, MSc; Samantha Jones, BSc. Silver Antimicrobial Dressings in Wound Management: A Comparison of Antibacterial, Physical, and Chemical Characteristics; 2009.

5. Nurlaily. Analisis beberapa faktor risiko terjadinya diabetes mellitus pada RSUD dr. Mm. Dunda Limboto Kab.Gorontalo 28 Juni 2014

6. Yudha, Suhartono T. Kejadian Ulkus Diabetes pada penderita DM tipe 2 dengan dan tanpa dislipidemia di RSUP Dr. Kariadi Semarang. Fakultas Kedokteran Undip Semarang; 2007.

7. Waspadji S. Komplikasi kronik Diabetes : Mekanisme Terjadinya Diagnosis dan Strategi pengelolaan. Dalam : Aru W, dkk, editors, Ilmu Penyakit Dalam,Jilid III, Edisi keempat, Jakarta; Penerbit FK UI ; 2006. 
8. Suryatono T. Hubungan Neuropati Diabetik dengan Ulkus Diabetika pada Pasien Rawat Inap di RSCM. Penyakit Dalam FK UI, Jakarta ; 2007.

9. Cahyaningsih D, Dahliaty A, Linggawati A. Sintesis dan karakterisasi membran bionanokomposit selulosa bakteri-ag sebagai membran antibakteri. JOM FMIPA. 2 (1): 222$231 ; 2013$.
10. Phillips PL, Wolcott RD, Fletcher J, Schultz GS. Biofilms Made Easy. Wounds International; 1(3): Available from http://www.woundsinternational.com ; 2010.

11. Aberdeen. Best Practice Statement. The use of topical antiseptic/antimicrobial agents in wound management Wounds, UK ; 2010. 